Article

\title{
Electrophoretic Deposition of Gentamicin-Loaded ZnHNTs-Chitosan on Titanium
}

\author{
Ahmed Humayun ${ }^{1}\left(\mathbb{D}\right.$, Yangyang Luo ${ }^{1}(\mathbb{D})$ and David K. Mills ${ }^{1,2, *(\mathbb{D})}$ \\ 1 Center for Biomedical Engineering and Rehabilitation Science, Louisiana Tech University, \\ Ruston, LA 71272, USA; ah.humayun@gmail.com (A.H.); yangyang317luo@gmail.com (Y.L.) \\ 2 School of Biological Sciences, Louisiana Tech University, Ruston, LA 71272, USA \\ * Correspondence: dkmills@latech.edu; Tel.: +1-318-257-2640
}

Received: 13 September 2020; Accepted: 30 September 2020; Published: 30 September 2020

\begin{abstract}
There is a need for titanium (Ti), an antimicrobial implant coating that provides sustained protection against bacterial infection. Chitosan (CS) coatings, combined with halloysite nanotubes (HNTs), are an attractive solution due to the inherent biocompatibility of halloysite, its ability to provide sustained drug release, and the antimicrobial properties of CS. In this study, the electrodeposition (EPD) method was used to coat titanium foil with CS blended with zinc-coated HNTs (ZnHNTs) and pre-loaded with the antibiotic gentamicin. The CS-ZnHNTs-gentamycin sulfate (GS) coatings were characterized using scanning electron microscopy (SEM), energy-dispersive spectroscopy (EDS), X-ray powder diffraction (XRD), X-ray fluorescence (XRF), Fourier-transform infrared spectroscopy (FTIR), and UV-visible spectroscopy. The coatings were further examined for their ability to sustain GS release, resist bacterial colonization and growth, and prevent biofilm formation. The CS-ZnHNTs-GS coatings were cytocompatible, exhibited significant antimicrobial properties, and supported pre-osteoblast cell proliferation. Hydroxyapatite also formed on the coatings after immersion in simulated body fluid. While the focus in this study was on zinc-coated HNTs doped into CS, our design offers tunability, as different metals can be coated onto the HNT surface and different drugs or growth factors loaded into the HNT lumen. Our results, and the potential for customization, suggest that these coatings have potential in the construction of an array of infection-resistant implant coatings.
\end{abstract}

Keywords: antibiotics; drug loading; electrodeposition; halloysite nanotubes; zinc; metal nanoparticles; titanium implants

\section{Introduction}

Implant failure due to peri-implantitis and its prevention is a significant area of focus in implant-coating research. A high implant failure rate due to biofilm formation is a significant source of implant-related infections resulting in implant removal surgery, additional antibiotic treatment, higher medical costs, prolonged hospital stays, and increased mortality [1-4]. Biofilm formation is also a severe threat due to an increase in antimicrobial resistance, which poses a serious global threat to human communities. Several strategies have been developed to prevent biofilm formation, including the use of localized drug-releasing bioactive coatings, drug-doped nanocontainers [5,6], coating with metal nanoparticles [7,8], peptides [9], and quaternary ammonium salts [10]. For many decades, stainless steel was the material of choice for orthopedic implants. It has been replaced with titanium, primarily due to its strength, durability, corrosion resistance, and improved biocompatibility. Titanium, however, also has drawbacks such as low osseointegration and biofouling leading to post-surgical infections, resulting in a variety of complications. This unwanted patient clinical condition can be remedied by coating antibacterial materials on the implant surface [11]. 
Chitosan, a naturally occurring biopolymer, is extracted by the chitin's diacylation and comprises the insect exoskeleton [12,13]. It is biocompatible, biodegradable, non-toxic, and antibacterial, thus making it a useful component of many biomedical applications [14]. Halloysite is an aluminosilicate nanotube comprising rolled-up sheets of silica and alumina, resulting in an oppositely charged outer surface and an inner core $[15,16]$. It has shown significant potential as a drug carrier, as its hollow core can be loaded with various substances that can be released in a sustained manner $[13,17]$. Thus, biocompatible composites with a sustained drug release capability can be created by blending chitosan with drug-loaded halloysite nanotubes (HNTs).

Electrophoretic deposition (EPD) is a two-step coating method involving the movement of charged materials under an applied electrical field and the subsequent accumulation and deposition of the charged material on the oppositely charged electrodes [14]. Previous studies have applied EPD to fabricate surface coatings of titanium nanoparticles under different alcohol solutions [15], zinc-halloysite substituted hydroxyapatite [16] and a chitosan (CS)-HNT bioactive glass composite [6]. This study explores using EPD to deposit chitosan combined with zinc-coated halloysite (ZnHNT) loaded with gentamicin (CS-ZnHNTs-gentamycin sulfate (GS)) as an antibacterial titanium coating. The synergistic activity of gentamicin and metal ions in preventing bacterial growth and biofilm formation was examined as well as its cytocompatibility and impact on pre-osteoblast cell proliferation and functionality. CS-ZnHNTs-GS coatings were shown to be cytocompatible. The synergistic activity of gentamicin and metal ions exhibited significant antimicrobial properties. The prevention of biofilm formation was correlated with zinc ion release. Furthermore, these coatings also supported pre-osteoblast cell proliferation and functionality.

\section{Materials and Methods}

\subsection{Materials}

Staphylococcus aureus(S. aureus) ATCC ${ }^{\circledR} 6538^{\mathrm{TM}} 50$ colony forming unit (CFU) (Manassas, VA, USA), chitosan (CS, $M W=200,000$ ) with a deacetylation degree of $85 \%$, HNTs, ethanol, acetic acid, acetone, phosphate-buffered saline (PBS), silicon carbide sandpaper, ninhydrin, gentamicin sulfate (GS), zinc sulphate heptahydrate $\left(\mathrm{ZnSO}_{4} \cdot 7 \mathrm{H}_{2} \mathrm{O}\right)$, titanium foil (Ti, $99.7 \%$ trace metals basis), o-ophthalaldehyde, $\beta$-mercaptoethanol, and isopropyl alcohol were purchased from Sigma-Aldrich (St. Louis, MO, USA). Platinum mesh electrodes, a VWR Accupower 500 electrophoresis power supply, and an ammeter (TP9605BT, TekPower, Seattle, WA, USA) were purchased from Amazon LLC.

\subsection{Electrolytic Metallization of HNTs}

ZnHNTs were prepared using a modified protocol based on an electrolytic method previously described by Mills et al. [17] (Figure 1). Briefly, an electrolysis setup was assembled consisting of two platinized titanium meshes held parallel at a 2-inch distance and connected to a DC power source (VWR Accupower 500 electrophoresis power supply). An ultrasonicated $100 \mathrm{~mL}$ aqueous solution of metal salts $(2.5 \mathrm{mM})$ and $50 \mathrm{mg}$ of HNTs were dispersed in glass beaker and subjected to $20 \mathrm{~V}$ at $80^{\circ} \mathrm{C}$ with polarity reversal at every $5 \mathrm{~min}$ [17] under constant stirring to reduce electrophoretic buildup at the working electrode and thus increase the ion density in the solution; afterwards, the supernatant was decanted thrice, and the solution was centrifuged at $5000 \mathrm{rpm}$ for $5 \mathrm{~min}$ with water to separate the ZnHNTs from non-adsorbed metal particles; they were dried at $30^{\circ} \mathrm{C}$. 


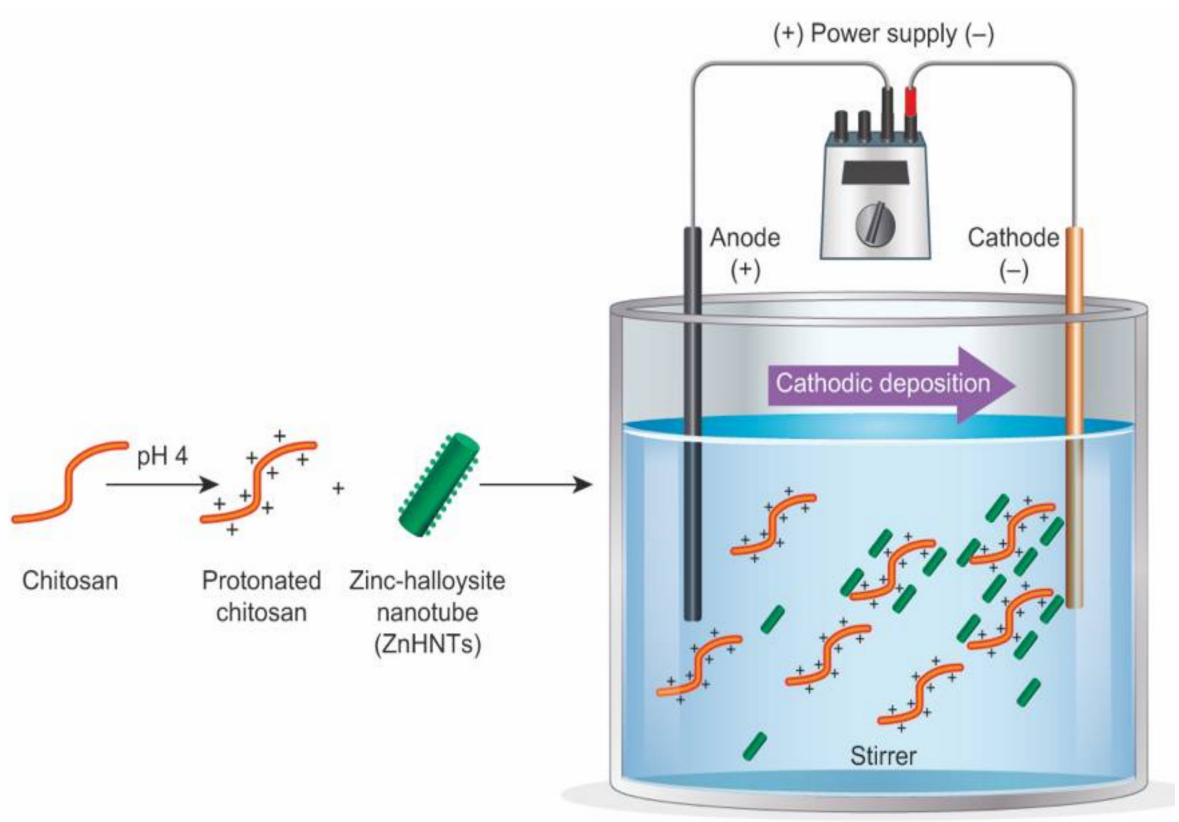

Figure 1. Graphical overview of the electrophoretic deposition process. An electrolysis setup consisting of two platinized titanium meshes held parallel at a 2-inch distance and connected to a DC power source. An ultrasonicated $100 \mathrm{~mL}$ aqueous solution of metal salts and HNTs were dispersed in a glass beaker and subjected to $20 \mathrm{~V}$ at $80^{\circ} \mathrm{C}$ with polarity reversal at every $5 \mathrm{~min}$ [18] under constant stirring. Afterwards, the supernatant was decanted thrice, and the solution was combined with water to separate the mHNTs from non-adsorbed metal particles; they were dried at $30^{\circ} \mathrm{C}$.

\subsection{Loading of HNTs with Gentamicin}

A vacuum loading technique was employed to load gentamicin sulfate (GS) into the ZnHNT lumen. Briefly, $25 \mathrm{mg}$ of GS was dispersed in $5 \mathrm{~mL}$ of PBS, mixed with $0.1 \mathrm{~g}$ of ZnHNTs, and placed under vacuum (28 pounds/square inch) overnight; the resulting product was decanted and washed. This process was repeated thrice to ensure the removal of free gentamicin.

\subsection{Electrophoretic Deposition of the Coatings on Titanium}

A $0.1 \mathrm{~g}$ solution of chitosan in $100 \mathrm{~mL}$ (3:1 distilled water/ethanol was prepared [6], and $1 \mathrm{~mL}$ of acetic acid was added in order to reduce the $\mathrm{pH}$ of the liquid, necessary for the protonation of chitosan, and $10 \mathrm{wt} . \%$ (0.01 g) GS-ZnHNTs were added. The solution was then magnetically stirred for $30 \mathrm{~min}$ [19].

Titanium foil was cut into $1 \mathrm{~cm} \times 3 \mathrm{~cm}$ dimensions, grounded with silicon carbide paper, washed with acetone and distilled water successively in order to remove surface oil, and treated with $4 \mathrm{~N}$ $\mathrm{NaOH}$ for 10 min to increase the hydrophilicity of the surface; excess $\mathrm{NaOH}$ was wiped off, and the foil was rinsed in distilled water and dried at $30^{\circ} \mathrm{C}$. Electrophoretic deposition was performed using a platinum mesh electrode $(5 \mathrm{~cm} \times 7.5 \mathrm{~cm})$ and titanium foil $(1 \mathrm{~cm} \times 3 \mathrm{~cm})$ held 1 inch apart, connected to $40 \mathrm{~V}$ DC power supply (VWR Accupower 500 electrophoresis power supply), functioning as an anode and cathode with a desktop ammeter (TekPower TP9605BT) connected in series; they were immersed into the solution, and electrophoresis was carried out for $10 \mathrm{~min}$ under room temperature. The samples were air-dried, and the before and after weights were recorded (Figure 1).

\subsection{Characterization of Titanium Coatings}

A S-4800 field-emission scanning electron microscope (SEM, Hitachi, Tokyo, Japan) was used to examine the surface morphology of the coated HNTs and to visually confirm the presence of the metal coating appearing as clusters on the otherwise smooth outer surface of the HNTs. SEM-EDS 
was carried out with an EDAX energy dispersive X-ray analyzer linked to the Hitachi S-4800 SEM to evaluate the elemental composition and weight percentage (wt.\%) deposition on the AgHNTs. EDS was operated at a working distance of $15 \mathrm{~mm}$ and an acceleration voltage of $15 \mathrm{kV}$; EDS spectra were analyzed using the EDAX Genesis software (6.43).

X-ray crystal diffraction analysis was performed on a Bruker D8 Venture diffractometer (Bruker, Karlsruhe, German) with $\mathrm{Cu} K \alpha 1$ radiation $(\lambda=1.5418 \AA$ ). The scan speed and step size used were $2 \mathrm{~s}$ and $0.02^{\circ}$, respectively; the diffraction patterns were recorded on a PW $1710 \mathrm{X}$-ray powder diffractometer (Philips, Amsterdam, Netherlands) over $2 \theta$ within $3^{\circ}$ to $85^{\circ}$.

The samples were analyzed using a Thermo/ARLQuant ${ }^{\prime} X$ energy dispersive $X$-ray fluorescence spectrometer. The $\mathrm{X}$-ray tube was operated at $30 \mathrm{kV}$ for 60 live seconds, using a $0.05 \mathrm{~mm}$ (thick) $\mathrm{Cu}$ primary beam filter in an air path for silver metal detection. The X-ray fluorescence (XRF) spectra were studied using the Wintrace 7.1 ${ }^{\mathrm{TM}}$ software (Thermo Fisher Scientific, Waltham, MA, USA).

The infrared spectrum was recorded at a resolution of $4 \mathrm{~s}^{-1}$ with 16 scans using a Thermo Scientific NICOLET ${ }^{\mathrm{TM}}$ IR100 FT-IR Spectrometer (Thermo Fisher Scientific, Waltham, MA, USA). The Thermo Scientific OMNIC ${ }^{\text {TM }}$ software was used to study the stretching bands.

Microplate absorbances were analyzed using a 800TS microplate reader (Biotek, Winooski, VT, USA) set at $630 \mathrm{~nm}$ absorbance.

\subsection{Gentamicin Release Analysis}

The drug release quantity was determined over a six-day period using a method previously described [20]. Briefly, Ti samples were placed in $1 \mathrm{~mL}$ of PBS and placed in a shaker, and $1 \mathrm{~mL}$ of sample was collected at regular time intervals and $1 \mathrm{~mL}$ PBS was replenished each time; $1 \mathrm{~mL}$ of collected PBS was mixed with o-phthaldialdehyde (OPTA) reagent (1 mL) and isopropyl alcohol (1 mL) and allowed to react for $30 \mathrm{~min}$ at room temperature, and the absorbance was measured at $335 \mathrm{~nm}$. OPTA regent was prepared by mixing $2.5 \mathrm{~g}$ of o-ophthalaldehyde, $3 \mathrm{~mL}$ of $\beta$-mercaptoethanol, 62 . $\mathrm{mL}$ of isopropanol, and $560 \mathrm{~mL}$ of 0.04 sodium borate. PBS was used as the blank, and the measured quantities of drugs were used to draw standard graphs [21].

\subsection{Antibacterial Analysis}

S. aureus was used in this study; it was maintained in tryptic soy agar. For testing, the bacterial strain was cultured in nutrient broth and plated on Müller-Hinton agar plates at $37^{\circ} \mathrm{C}$ overnight, after which a single colony was picked up using a sterile toothpick, suspended in saline solution, and diluted to $0.5 \mathrm{McF}$ arland standards $\left(1.5 \times 10^{8} \mathrm{CFU} / \mathrm{mL}\right), 20 \mu \mathrm{L}$ of which was spread over Müller-Hinton agar plates on which the test materials were placed and incubated for $12-18 \mathrm{~h}$ at $37^{\circ} \mathrm{C}$, and the obtained zones of inhibition were analyzed using the ImageJ software.

The antibacterial potential was also evaluated for $S$. aureus using a microdilution broth assay. Briefly, $1 \mathrm{~cm} \times 1 \mathrm{~cm}$ samples were cut and immersed in 24-well plates containing $3 \mathrm{~mL} /$ well of Müller-Hinton broth inoculated with $20 \mu \mathrm{L}$ of $0.5 \mathrm{McFarland}$ standard S. aureus; the plates were put on a shaker; after $4 \mathrm{~h}$, the samples were removed, and the absorbance of $100 \mu \mathrm{L}$ of the solutions was recorded after $12 \mathrm{~h}$.

A bacterial adherence assay was performed by immersing samples into $1-3 \mathrm{~mL} /$ well of Müller-Hinton broth (depending on the sample dimension) inoculated with $20 \mu \mathrm{L}$ of 0.5 McFarland standard S. aureus, the plates were put on a shaker, and the samples were removed after $1 \mathrm{~h}$; the absorbance of $100 \mu \mathrm{L}$ of the solutions was recorded after $12 \mathrm{~h}$ [22].

A biofilm assay was performed using the crystal violet assay. Briefly, samples were incubated in $2 \mathrm{~mL}$ of nutrient broth in 48 -well plates inoculated with $1 \mathrm{OD}$ S. aureus for 2 days at $37^{\circ} \mathrm{C}$, at the end of which the plate was emptied by inverting with gentle tapping in order to remove lightly attached planktonic bacteria. The remaining bacterial films were stained with aqueous crystal violet $(0.1 \% w / v)$ for $10 \mathrm{~min}$, which was similarly removed by inversion and tapping to ensure the optimal removal of 
unattached bacteria. Acetic acid (30\%) was then added to each well to solubilize the stains, and the absorbance at $630 \mathrm{~nm}$ was recorded [23].

\subsection{In Vitro Bioactivity Tests}

In vitro bioactivity was assessed by using $5 \times$ simulated body fluid (SBF) prepared using a modified protocol [24] based on the method of Kokubo et al. [25]. The samples were immersed in $3 \mathrm{~mL}$ of $5 \times \mathrm{SBF}$ at $37^{\circ} \mathrm{C}$ for 1 week; after immersion, the samples were taken out and dried at room temperature. SEM-EDS was performed on the samples to detect the formation of hydroxyapatite (HA).

\subsection{Cell Culture}

$1 \mathrm{~cm} \times 1 \mathrm{~cm}$ samples were sterilized in a UV chamber for $60 \mathrm{~min}$. Cell viability was studied by co-culturing pre-osteoblast cells (MC3T3) with mHNTs. The cells were obtained from the American Type Culture Collection (ATCC, Manassas, VA, USA). Cryovials were thawed and allowed to equilibrate in a water bath within a humidified $\mathrm{CO}_{2}$ incubator at $37^{\circ} \mathrm{C}$. The cells thus obtained were cultured in $\mathrm{T} 25$ flasks in alpha MEM growth media (Hyclone, GE Life Sciences, Marlborough, MA, USA) containing $10 \%$ FBS and 1\% penicillin (complete medium) through to passage four and then frozen down and maintained in a liquid nitrogen Dewar until use. Trypsin-EDTA $(0.25 \%$ trypsin, $1 \mathrm{mM}$ EDTA $)$ was used to detach the cells from the culture flasks.

For each experiment $(n=3)$, pre-osteoblasts were thawed and prepared as described above and used when they subsequently achieved sub-confluency. For every cell study, pre-osteoblast cells were seeded in 48-well plates at a concentration of $1 \times 10^{5}$ cells/ well. After $24 \mathrm{~h}$ of incubation, $25 \mu \mathrm{g} / \mathrm{mL}$ metalized HNTs (mHNTs) were added into each well for another $24 \mathrm{~h}$ of incubation. Then, the cells were used to assess the potential cytotoxicity (Live/Dead assay) and cell proliferation (MTS assay).

\subsection{Live/Dead Cytotoxicity Tests and Cell Proliferation Studies}

Ti implants with different coatings were placed into 48-well plates. Each coating group had 3 samples. Pre-osteoblast cells were seeded into each well at a concentration of $1 \times 10^{5}$ cells/well. Cells cultured in wells without Ti implants were used as controls. Cells were cultured at $37^{\circ} \mathrm{C}$ for $24 \mathrm{~h}$. Cell viability was assessed using the LIVE/DEAD ${ }^{\circledR}$ Viability/Cytotoxicity Kit (ThermoFisher, Waltham, MA, USA); it contains the polyanionic dye calcein, which is retained within living cells and produces an intense uniform green fluorescence (excitation/emission $\sim 495 \mathrm{~nm} / \sim 515 \mathrm{~nm}$ ), and EthD-1, which enters cells with damaged membranes and produces a bright red fluorescence in dead cells (excitation/emission $\sim 495 \mathrm{~nm} / \sim 635 \mathrm{~nm}$ ).

For viability studies, the staining solution was prepared by mixing $5 \mu \mathrm{L}$ of $4 \mathrm{mM}$ Calcein AM Solution and $20 \mu \mathrm{L}$ of $2 \mathrm{mM}$ EthD-III Solution with $10 \mathrm{~mL}$ of DPBS. Cells were washed twice with DBSS, and then, $50 \mu \mathrm{L}$ of staining solution was added to each well. Then, the cells were incubated at room temperature for $30 \mathrm{~min}$ in darkness. Each cytotoxicity experiment was repeated three times. Images were captured using an Olympus BX51 fluorescence microscope (Olympus Corporation, Tokyo, Japan) equipped with an Olympus DP11 digital camera system. Image [26] was used for counting fluorescent cells from thresholded 8-bit images at a cell size limit of 50-200 pixels ${ }^{2}$.

Cell proliferation was assessed with the MTS colorimetric assay, which is based on the reduction of the MTS tetrazolium compound to a colored formazan product soluble in culture media. Cells were cultured as above for $24 \mathrm{~h}$, and then, $40 \mu \mathrm{L}$ of MTS reagent was added to each well and incubated at $37^{\circ} \mathrm{C}$ for $2 \mathrm{~h}$. The absorbance value at $490 \mathrm{~nm}$ was recorded; the background absorbance was determined from the medium wells, which only contained cell culture medium, and subtracted.

\subsection{Statistical Analysis}

All experiments were performed in triplicate, and the results are reported as mean \pm standard deviation. One-way analysis of variance (ANOVA) with $p<0.05$ as the significance level was utilized 
for statistical analysis. Statistical analysis was performed using the Microsoft Excel Analysis ToolPak plugin and Origin 9.6. Linear regression was used to construct and correlate standard curves.

\section{Results and Discussion}

GS adsorbed to the outer surface of the ZnHNTs due to its Si-O-Si negatively charged bonds, whereas the application of a vacuum creates negative pressure inside the ZnHNT lumen and facilitates drug loading [27]. Chitosan is necessary for the EPD of ZnHNTs-GS, as it not only stabilized the suspension but also provided the required net positive charge for deposition on the negatively charged cathode [5]. Chitosan dissolves by protonation through acetic acid addition, resulting in $\mathrm{pH}$ reduction, increased conductivity, and adsorption onto the ZnHNTs [19].

$$
\mathrm{CH}_{3} \mathrm{COOH}+\mathrm{CS}-\mathrm{NH}_{2} \leftrightarrow \mathrm{CH}_{3} \mathrm{COO}^{-}+\mathrm{CS}-\mathrm{NH}_{3}{ }^{+}
$$

At the cathode, the electrolysis of water occurs, generating the hydroxyl ion $\left(\mathrm{OH}^{-}\right)$, which deprotonates the CS- $\mathrm{NH}_{3}{ }^{+}$, resulting in CS- $\mathrm{NH}_{2}[5,28,29]$. Several recent studies have examined the use of GS as an HNT coating, with several ingenious methods developed for their use in drug delivery $[28,29]$. HNTs wrapped by chitosan layers appear to be a very effective means for drug delivery.

Samples examined using laser confocal microscopy revealed a thin layer of the CS coated on the surface of the Ti foil (Figure 2).

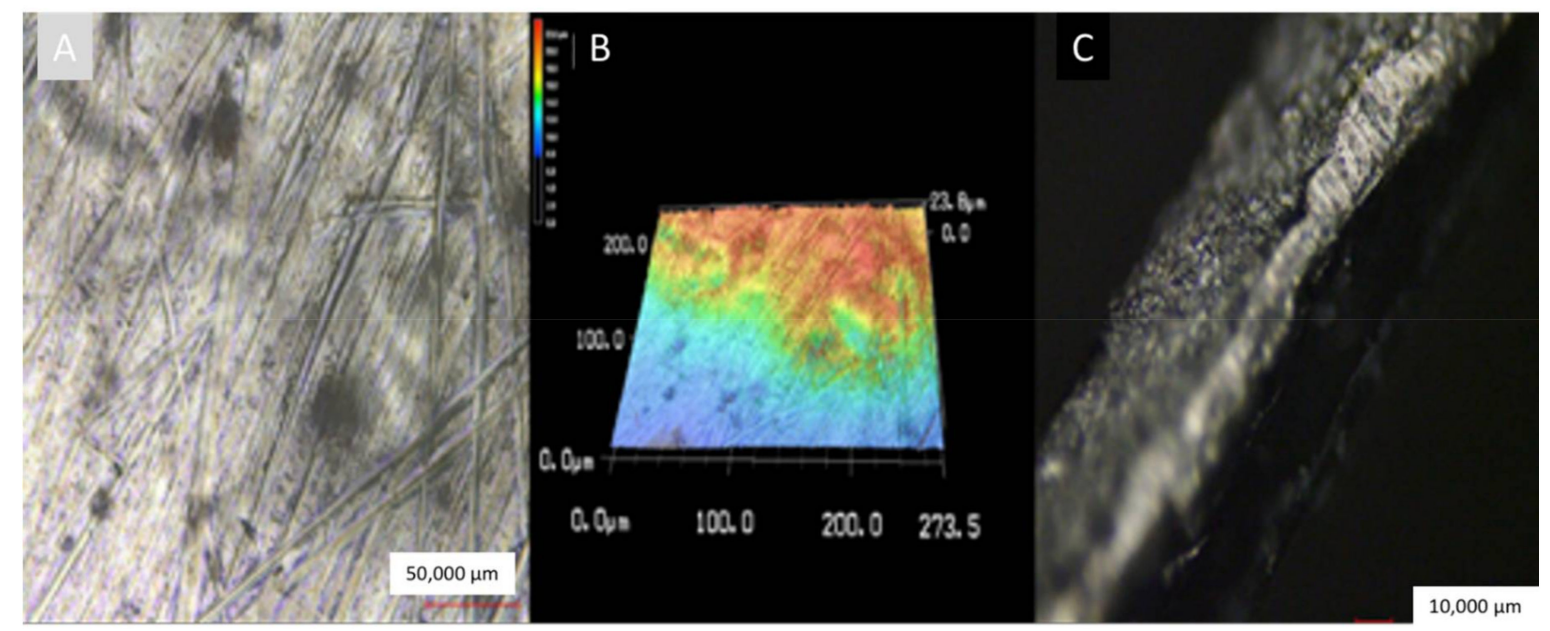

Figure 2. (A,C) Laser confocal image of chitosan (CS)-ZnHNTs-gentamycin sulfate (GS) coating; (B) 3D topography of the coated Ti foil.

As shown in the SEM micrograph in Figure 3, a uniform layer of chitosan was observed on all samples. A thin layer of chitosan with circular areas with no deposition was electrodeposited on titanium; the smooth morphology of the chitosan (Figure 3A) was disrupted with the addition of mHNTs that appeared uniformly distributed across the chitosan-coated Ti surface (Figure 3B). The ZnHNTs exhibited a circular morphology on the surface, indicative of the presence of HNTs with varyingly sized $Z$ nHNTs visible across the Ti surface. 


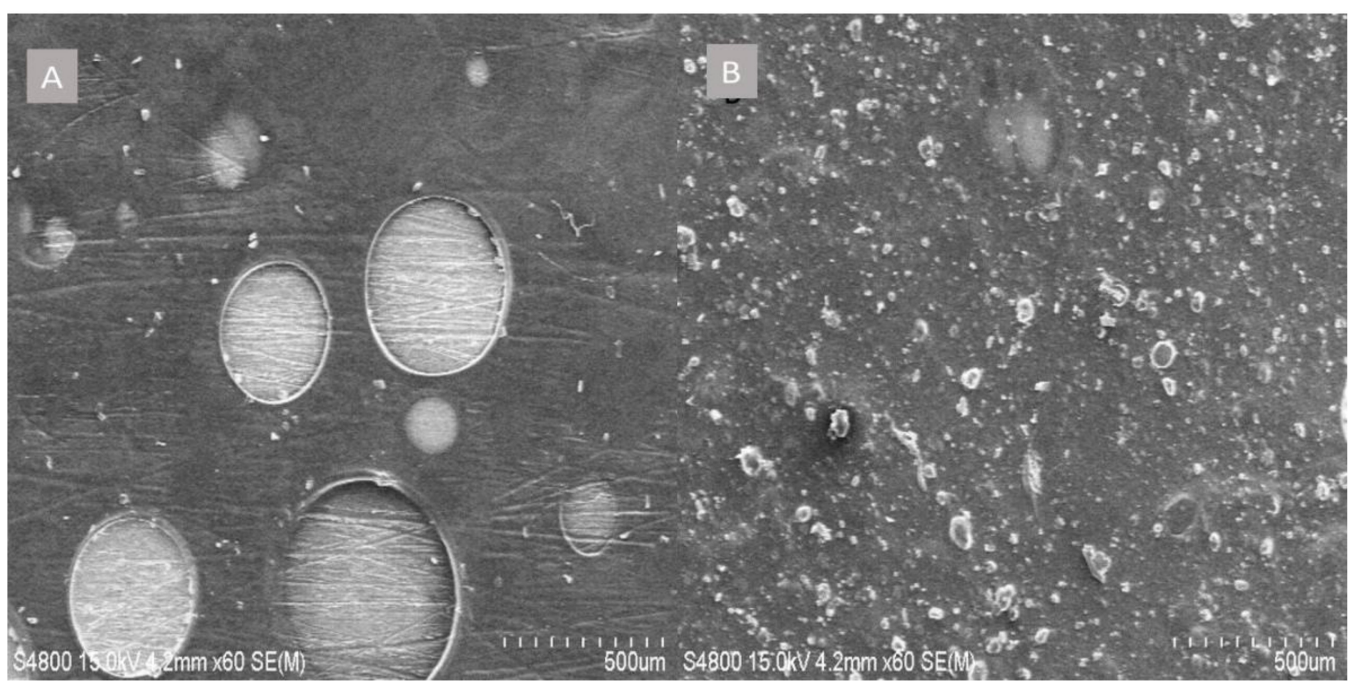

Figure 3. SEM micrograph of (A) chitosan and (B) CS-ZnHNTs-GS deposits.

In Figure 4, the elemental mapping results confirmed the presence of uniformly interspersed ZnHNTs distributed throughout the coatings. Furthermore, in the EDS spectra, strong silicon, aluminum, and zinc peaks were observed confirming their presence.

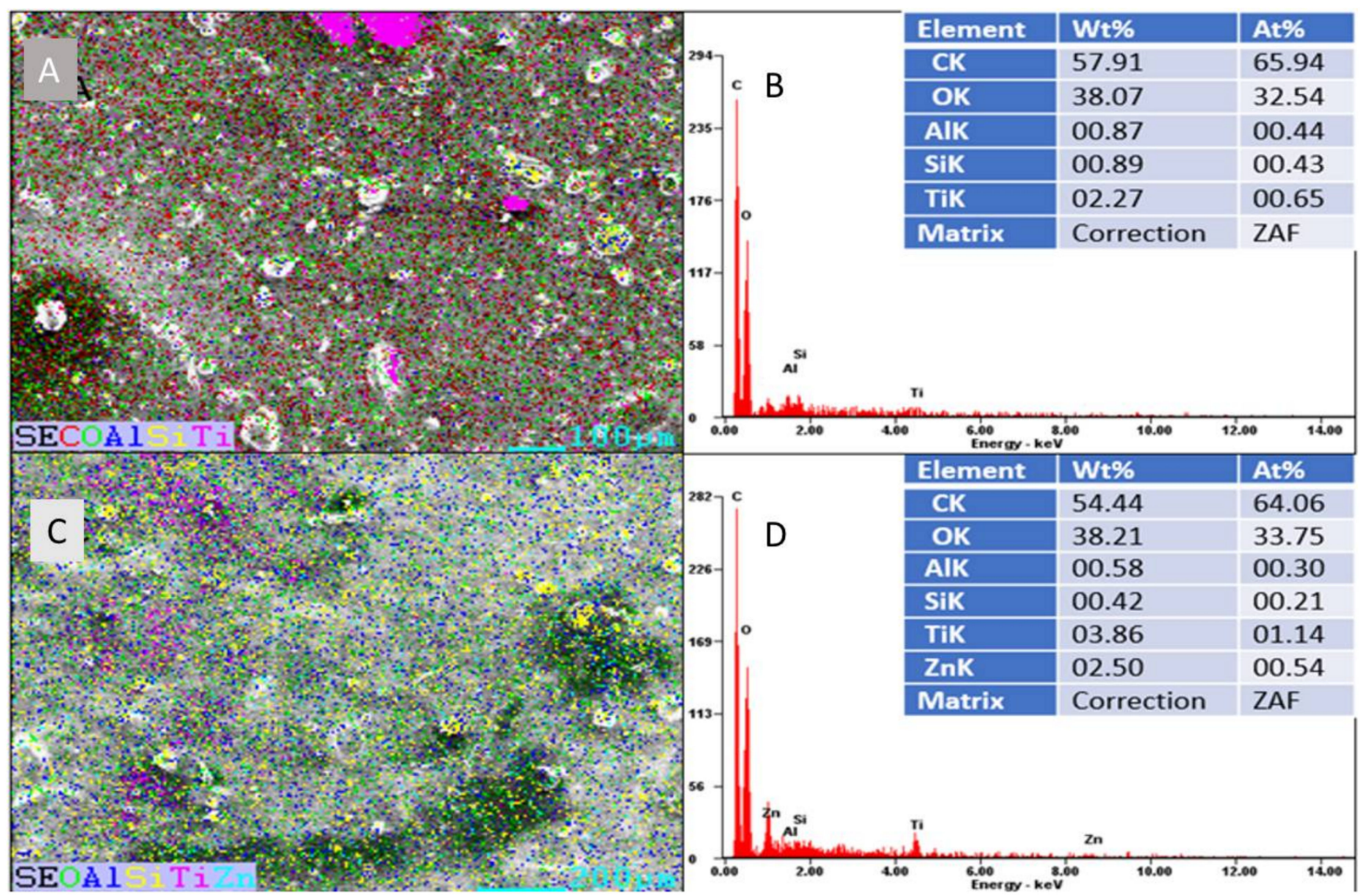

Figure 4. EDS mapping of (A,B) CS-HNTs and (C,D) CS-ZnHNTs; a more uniform surface with less titanium base metal visibility was obtained, which could be due to the increased conductance of the electrophoretic deposition upon the addition of ZnHNTs.

FTIR was used for chemical analysis and the identification of the characteristic bands for chitosan at 3400 (O-H stretch) and $2940 \mathrm{~cm}^{-1}$ (C-H stretch), respectively, and peaks for the secondary amide group bending were observed at $1644 \mathrm{~cm}^{-1}$. Upon the addition of ZnHNTs, new peaks were observed at 1031 and $1090 \mathrm{~cm}^{-1}$, respectively, which correspond to the in-plane Si-O stretching of HNTs, with new peaks at 1278 and $1401 \mathrm{~cm}^{-1}$, respectively, that can be ascribed to the $\mathrm{C}-\mathrm{N}$ stretching of gentamicin [30] (Figure 5). 


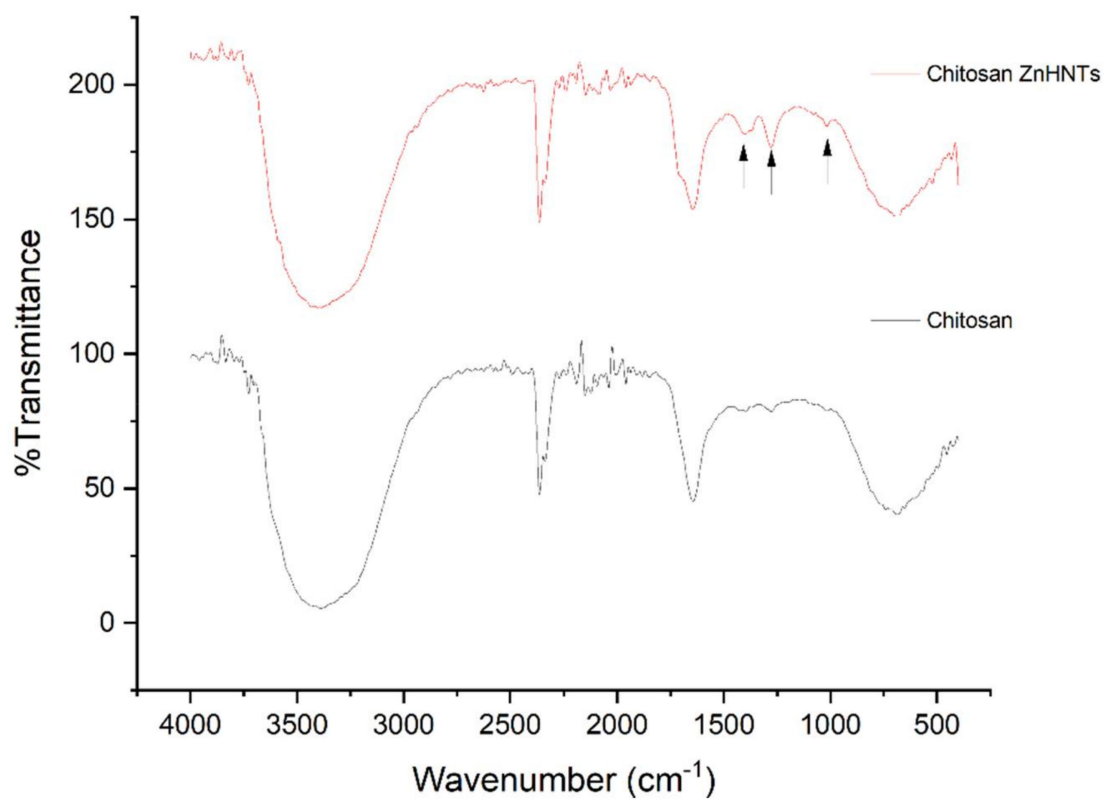

Figure 5. FTIR spectra of the coatings. Arrow depicts the new peaks observed upon the addition of ZnHNTs-GS at 1028 (in-plane Si-O stretching of HNTs), 1278 and $1401 \mathrm{~cm}^{-1}$ corresponding to the C-N stretching of gentamicin.

In the XRD spectra of the coatings, a broad peak at $20^{\circ}$ was observed, which is attributable to the crystalline structure of chitosan (denoted by $*$ ), and peaks at 12,20 , and $25^{\circ}$ were observed for the (001), (020), and (002) planes of HNTs. CS-ZnHNTs displayed the peaks corresponding to $\mathrm{ZnO}$ at $31^{\circ}, 34^{\circ}$, $36^{\circ}, 47^{\circ}, 56^{\circ}, 63^{\circ}$, and $68^{\circ}$ corresponding to the (100), (002), (101), (102), (110), (103), and (112) planes, respectively (Figure 6) [31,32]. Figure 7 shows the current density for the EPD at $40 \mathrm{~V}$ in an ethanolic solution, and it remained almost constant during the process. Furthermore, the addition of acetic acid helped in chitosan protonation and increased with the current. The addition of ZnHNTs resulted in an elevated amperage.

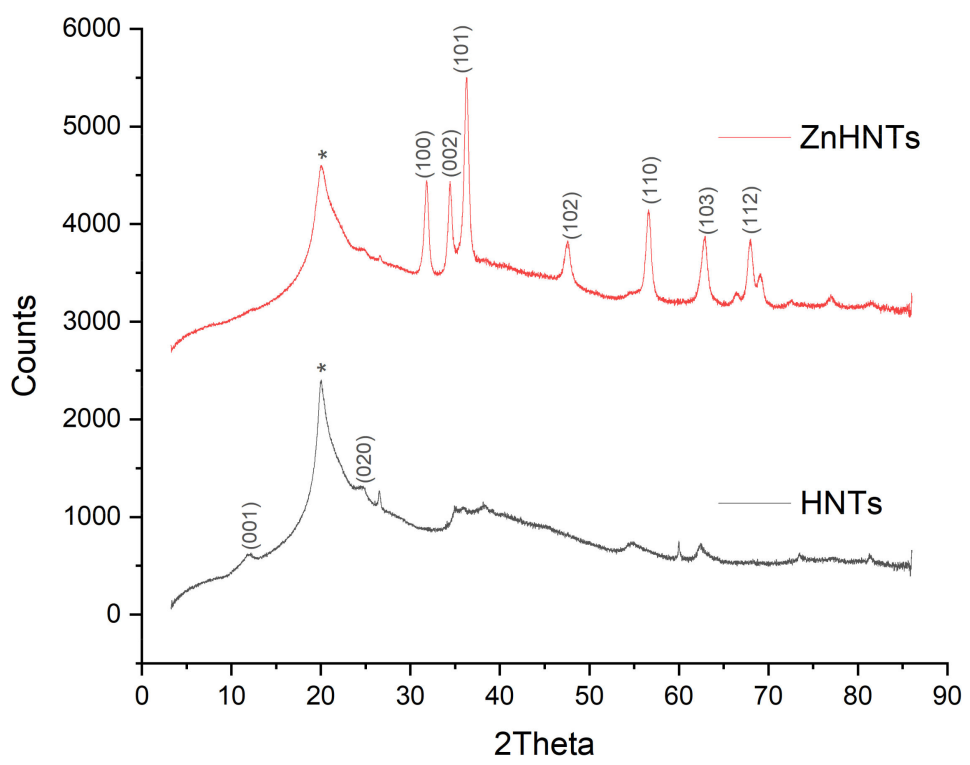

Figure 6. XRD profile of CS-HNTs and CS-ZnHNTs. 


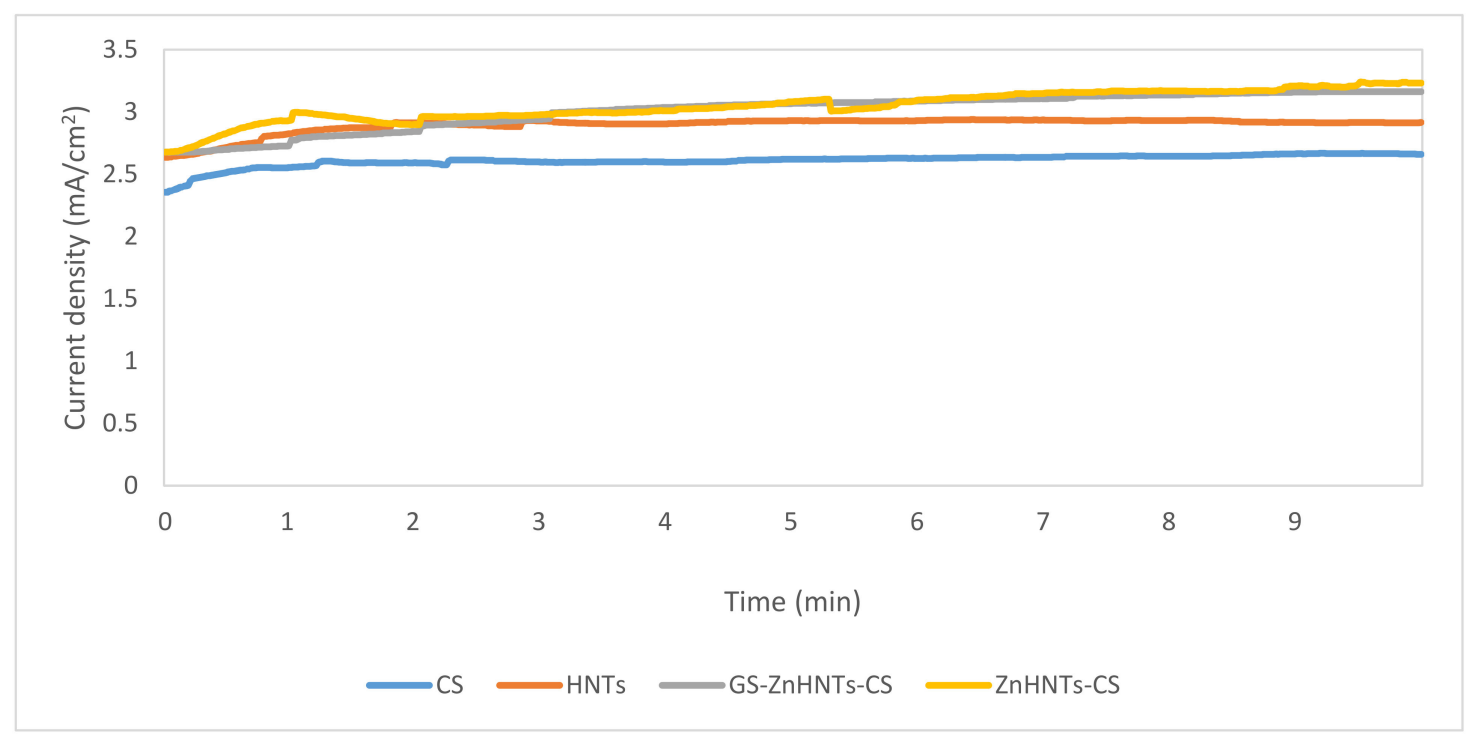

Figure 7. Current density during electrodeposition (EPD) at $40 \mathrm{~V}$. The addition of ZnHNTs in the chitosan leads to increased current density, explainable based on increased conductivity due to ionic species leaching from ZnHNTs.

The bacterial infection of implants is the leading cause of implant failure [33]. Bacterial adhesion, growth, and biofilm formation after implantation can induce severe complications for the patient [34]. Different approaches for producing antimicrobial medical devices have been studied. Surface functionalization, with different components, including antibiotics, antimicrobial dyes, quants, and other antibacterial bioactives, has been a significant research focus [30]. Metal nanoparticles exhibit robust antimicrobial action, especially copper, silver, and zinc oxide. Several recent studies have used coating solutions containing CS and metal nanoparticles. Copper [35], silver [36], titanium dioxide [37], and zinc [38] were the most commonly used metal nanoparticles.

The present study had a very similar motive, with a goal of developing a biomaterial surface coating possessing antimicrobial capability and, in this case, studying the combined effect on a known antimicrobial nanoparticle (zinc) and gentamycin-doped HNTs. The antibacterial potential of the coatings was evaluated for Gram-positive $>S$. aureus bacteria using the agar diffusion method. $C S$ and HNTs alone did not induce an antibacterial response (Figure 8A,B), while ZnHNTs-CS produced a large inhibitory effect (Figure 8C). By contrast, CS-ZnHNTs-GS exhibited significant inhibition zones of $3.11 \pm 0.79 \mathrm{~cm}^{2} /$ unit area of the sample (Figure $8 \mathrm{D}$ ), and a similar pattern was observed in the antimicrobial broth testing (Figure 8E). A similar bacterial adhesion assay showed similar antibacterial activity but a diminished trend as compared to that shown by broth testing (Figure 9B). In addition, fewer adherent planktonic bacteria were found (Figure 9B). 

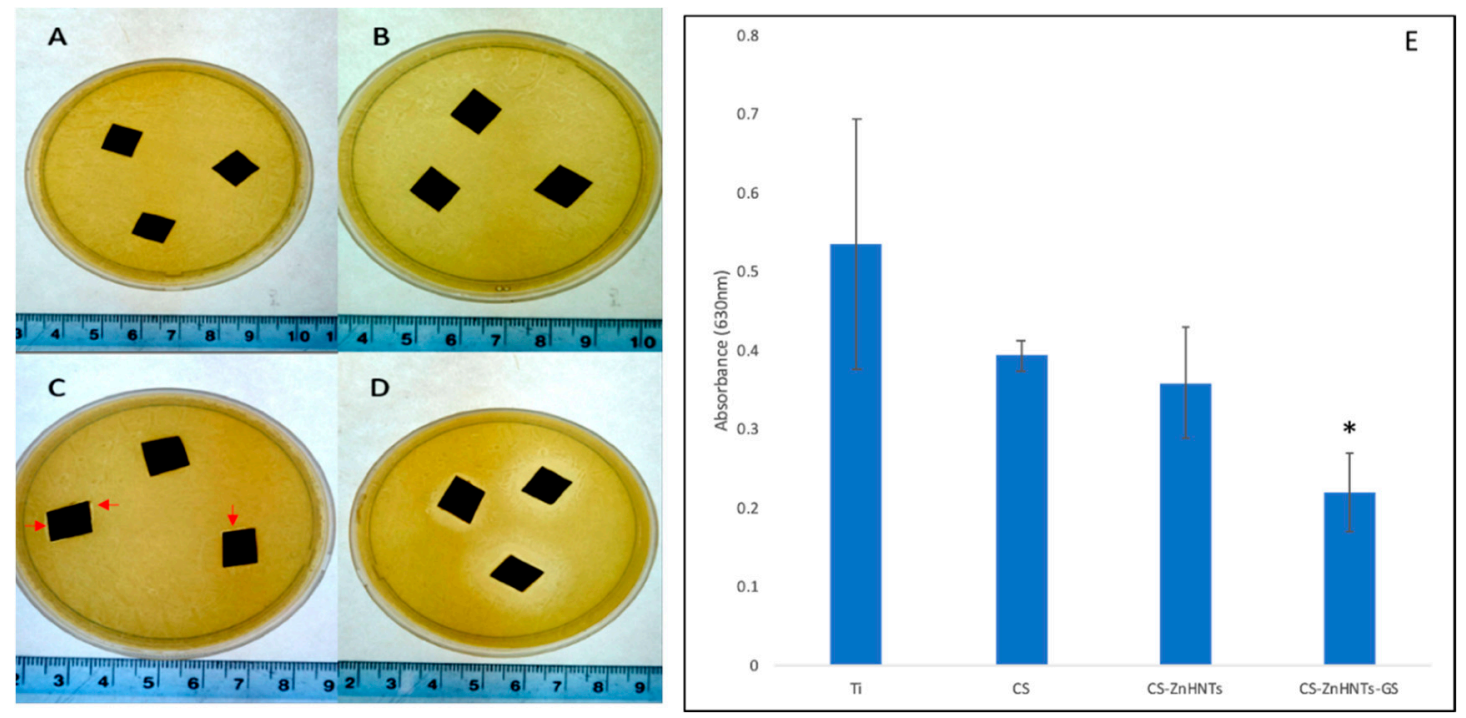

Figure 8. Disc diffusion assay for S. aureus. (A) CS, (B) HNTs-CS, (C) ZnHNTs-CS, and (D) GS-ZnHNTs-CS. (E) Antimicrobial broth testing. GS-ZnHNTs-CS exhibited the highest bacteriostatic effect. Bars $=$ mean \pm standard deviation. ${ }^{*}=$ significant difference, $p<0.05(n=3)$.
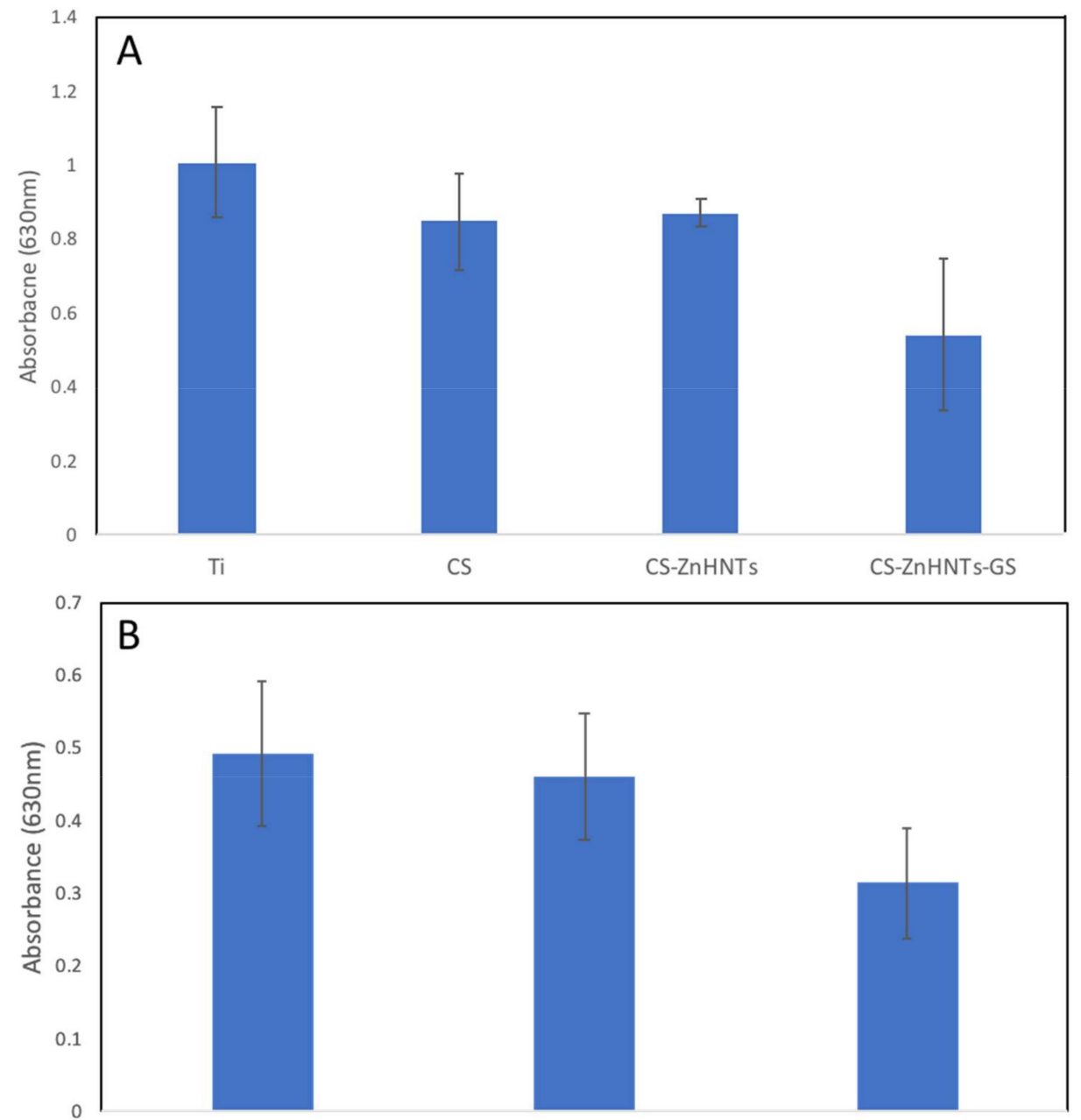

CS

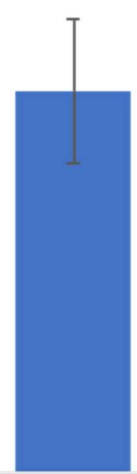

CS-ZnHNTs ic 
Crystal violet is a basic dye that binds to the peptidoglycan layers of Gram-positive and negative bacteria [39]. The samples on staining with crystal violet displayed less biofilm formation on the implant surface on the incorporation of ZnHNTs-GS (Figure 10); this may be attributed to zinc ions leaching from the coatings (Figure 11) and the release of gentamicin from the HNT lumen (Figure 12). Ti samples were placed in $3 \mathrm{~mL}$ PBS, placed in an orbital shaker and $3 \mathrm{~mL}$ of sample was analyzed at regular intervals of time $(1,24,48,72 \mathrm{~h})$, the PBS sample was restored to the original container after XRF analysis.

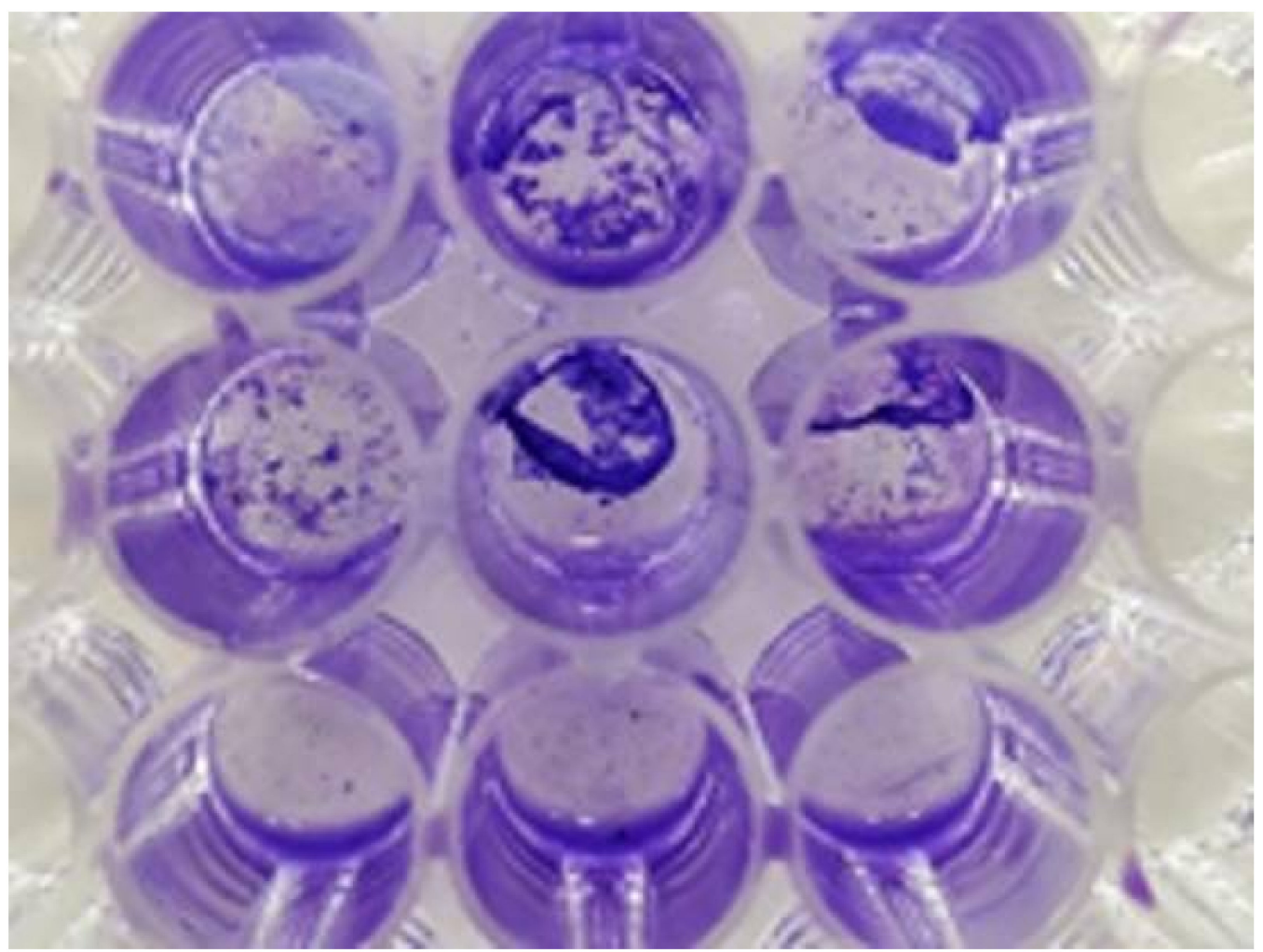

Figure 10. Crystal violet-stained biofilms in CS, CS-ZnHNTs, and CS-ZnHNTs-GS wells (top-bottom, respectively).

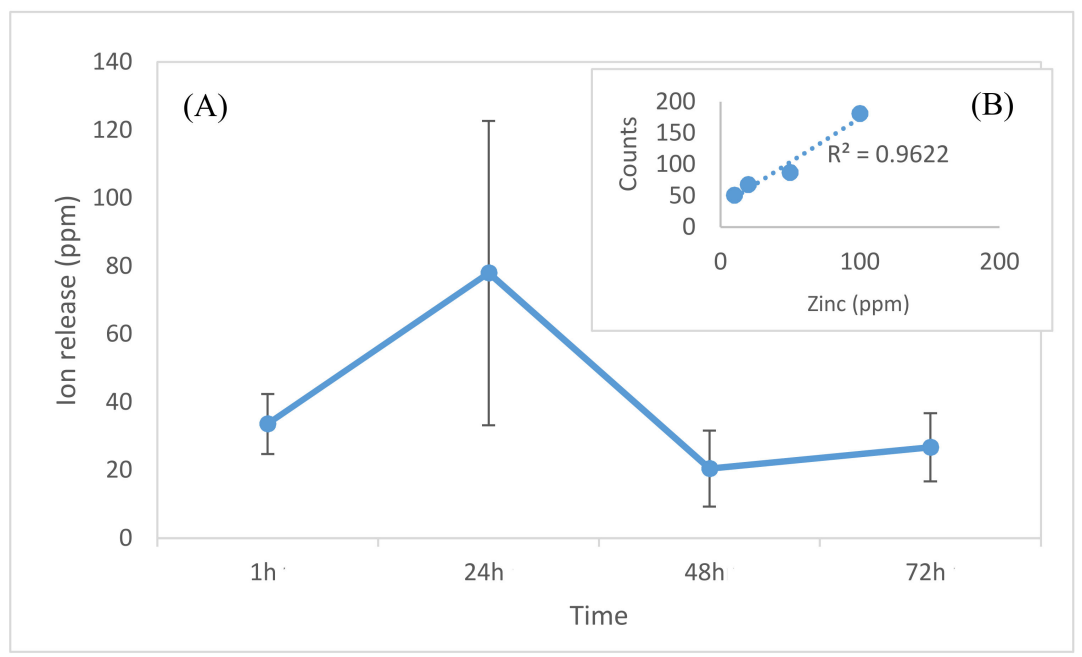

Figure 11. (A) Zinc ion release from the CS-ZnHNTs-GS coatings; highest ion release concentration was observed at $24 \mathrm{~h}(n=5)$, (B-zinc ion standard X-ray fluorescence (XRF) curve). 
Additionally, the total GS content on the surface of the implant coatings was estimated by dipping the samples into a ninhydrin reagent $(2.12 \pm 0.81 \mathrm{mg} / \mathrm{mL}$ was obtained, $n=5)$. The data show that the gentamicin-loaded ZnHNTs-chitosan coatings possesses antibacterial activity, which can be attributed mainly to the gentamicin antibiotic. Additionally, the release of zinc ions, as well as the positively charged chitosan surface, leads to interaction with the negatively charged bacterial membranes, further enhancing the antibacterial effect.

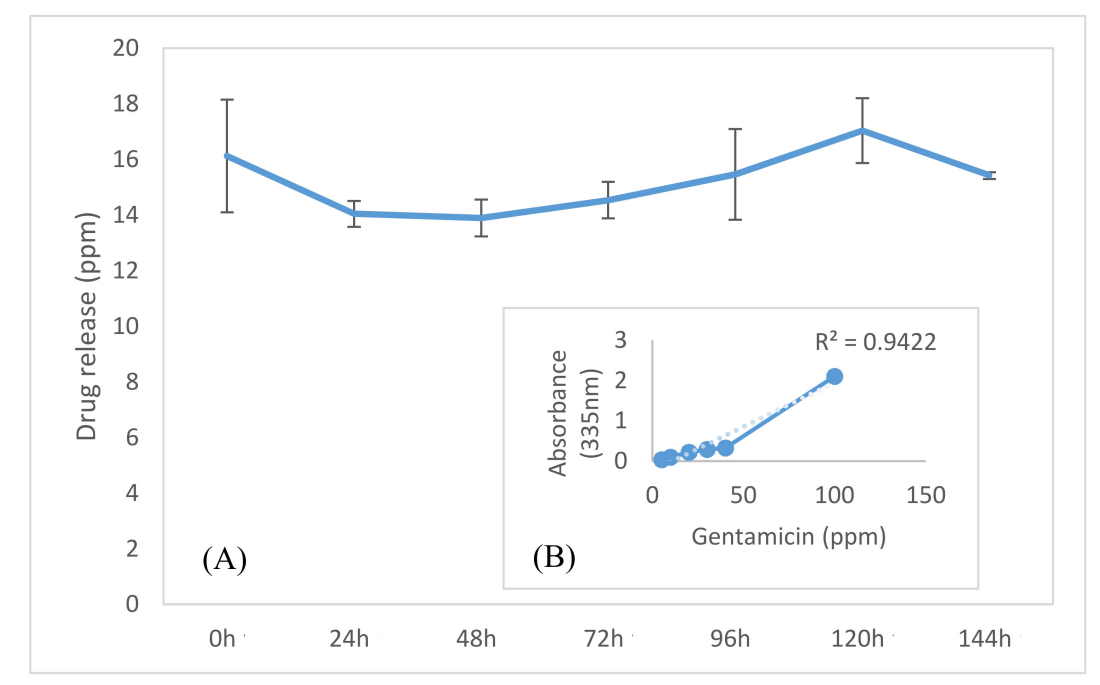

Figure 12. (A) Gentamicin release from CS-ZnHNTs-GS coatings (ppm). A gradual burst of drug release was observed, which could be due to drug adsorption on the mHNTs' outer surface and chitosan coating. (B-gentamicin standard XRF curve.) $(n=5$.)

Cytocompatibility was assessed using a Live/Dead assay. As shown in Figure 13, there were few dead cells detected on the substrates containing ZnHNTs (Figure 13(3b,4b)). The total numbers of live and dead cells were counted using the ImageJ software, and the total cell viability was plotted, as shown in Figure 14. An ANOVA analysis did not show significant differences between each coating type and the control group; however, the CS-ZnHNTs and CS-ZnHNTs-GS groups exhibited slightly higher cell viability. One possible explanation for this observation is the $\mathrm{Zn}^{+}$ion release. Zinc is an essential element in human health, has been found as a component in over 100 enzymes, and also plays a crucial role in cell proliferation and DNA synthesis [40]. Additionally, zinc is an antioxidant and helps to prevent free radical-induced injury [41]. In this study, as zinc was released from the HNT surface, it was taken up by surrounding cells, contributing to enhanced cell viability. 


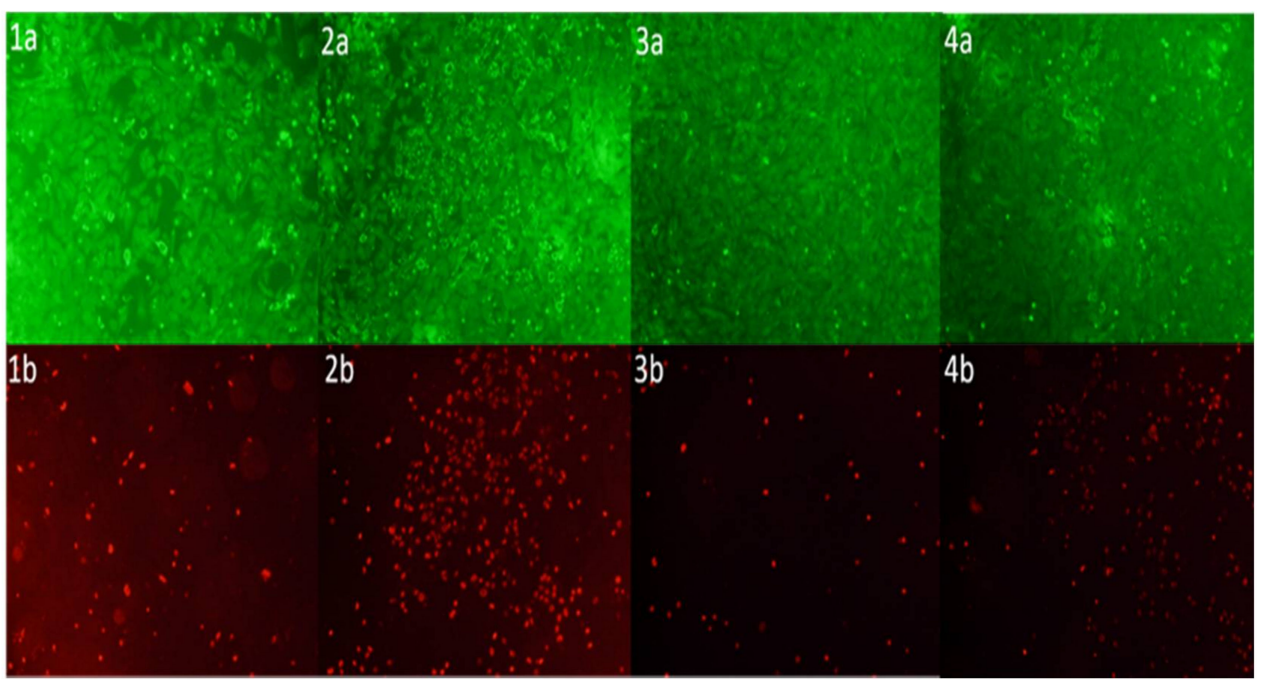

Figure 13. Live/Dead assay; pre-osteoblast cells were cultured in the presence of Ti foil scaffolds: (1a,b) CS, (2a,b) HNTs-CS, (3a,b) ZnHNTs-CS, and (4a,b) GS-ZnHNTs-CS. Live cells (green) and dead cells (red). ZnHNTs led to increased cellular viability.

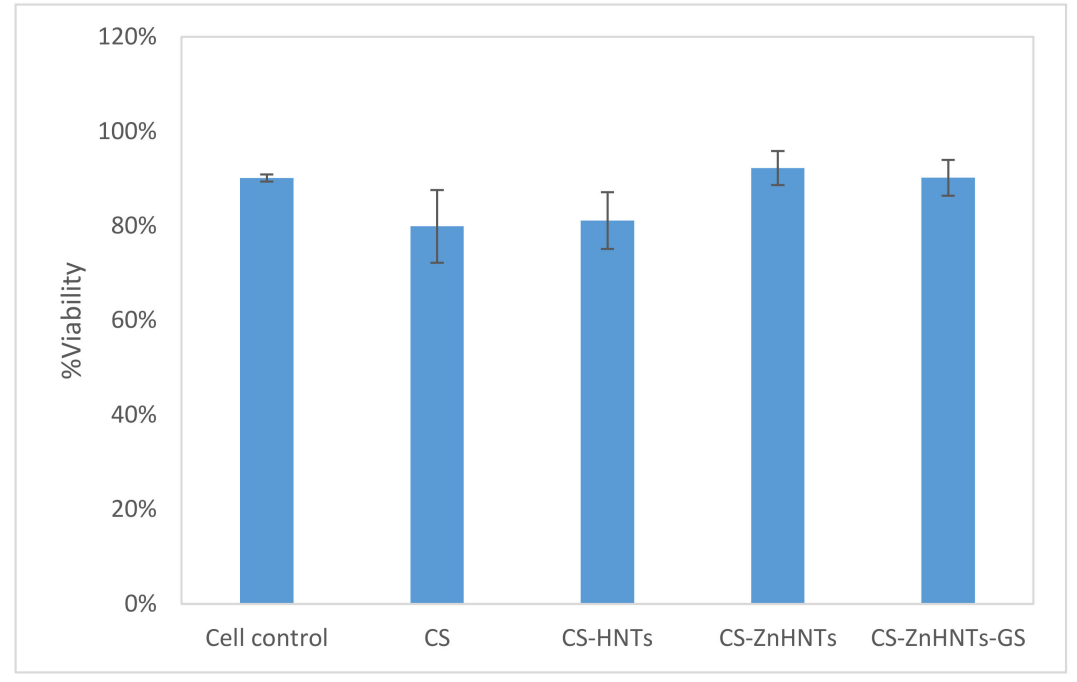

Figure 14. Cell viability assay for Ti foil scaffolds; the CS-ZnHNTs coating had the highest cell viability $(92 \%)$.

Cell proliferation in response to CS-ZnHNTs and CS-ZnHNTs-GS was analyzed using the MTS assay. As shown in Figure 15, when compared to the control group, the cells cultured on all the zinc/HNT-coated Ti implants showed a reduction in cell proliferation, and after $24 \mathrm{~h}$ of incubation, the cells grown on Ti implants exhibited reduced proliferation. This was an unexpected observation. One explanation may be deficient surface cell adhesion properties in the zinc-coated Ti groups that led to reduced cell attachment on the coated Ti surface after plating. Cell culture plates are treated to promote cell attachment, and their surface contains hydroxyl and carboxyl groups, which promotes cell attachment. In this study, the coated Ti implants did not include any specific cell adhesion peptides or ligands to promote cell attachment and the CS was unmodified, and this may have led to a reduced number of cells adhering to the Ti surfaces during initial cell seeding. Many studies have modified CS through plasma treatment to encourage cell attachment [42]. The surface treatment of CS is an effective way of improving the biocompatibility of chitosan membranes for their use in biomedical applications. 


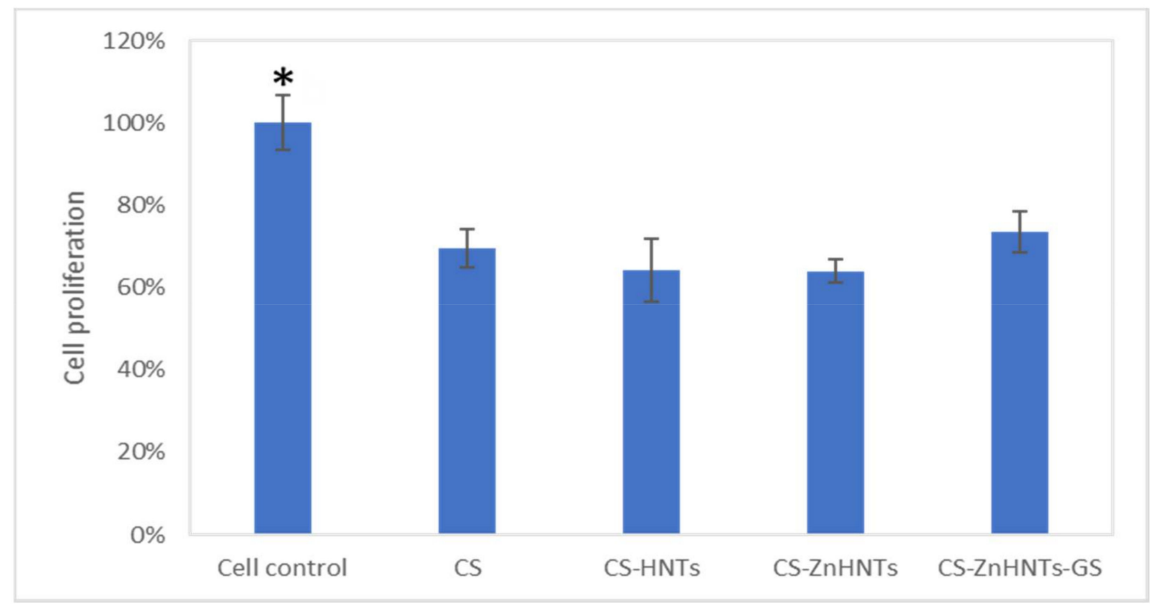

Figure 15. Proliferation assay for the Ti foil scaffolds after $24 \mathrm{~h}$ of incubation. ${ }^{*}=$ statistically significant at $p<0.05$.

Cell proliferation on Ti implant coatings improved after $24 \mathrm{~h}$, and after an increased incubation time, cell proliferation was similar to that in the control group, demonstrating that all the coatings are cytocompatible (Figure 15); the presence of Zn may promote cell proliferation. It has been reported that the addition of $\mathrm{Zn}$ led to increased bone marrow stem cell proliferation [43]. Another study showed that $\mathrm{Zn}$ increased antimicrobial and osteogenic activity [44], and similar results have been found when $\mathrm{Zn}$ was incorporated with magnesium ions [45].

Cumulatively, the data show that the CS-ZnHNTs-GS coatings possess significant antibacterial activity, which can be attributed largely to the release of gentamicin. Additionally, the release of zinc ions, as well as the positively charged chitosan surface, might have led to increased interactions with negatively charged bacterial membranes and resulted in the supplementary enhancement of the antibacterial effect. Increased cellular viability and proliferation were also observed with exposure to ZnHNTs. Hydroxyapatite was also observed to have formed on the samples after immersion in SBF (Figure 16). As an essential mineral required for normal skeletal growth and bone maintenance, zinc can positively affect chondrocyte and osteoblast functions, while inhibiting osteoclast activity [46,47]. Hydroxyapatite formation is an indication of the potential of CS-ZnHNT coatings in promoting bone formation leading to osseointegration [47-49]. However, further investigation of its potential to induce osteoblast differentiation leading to bone tissue formation and mineralization will be required to validate its potential. 

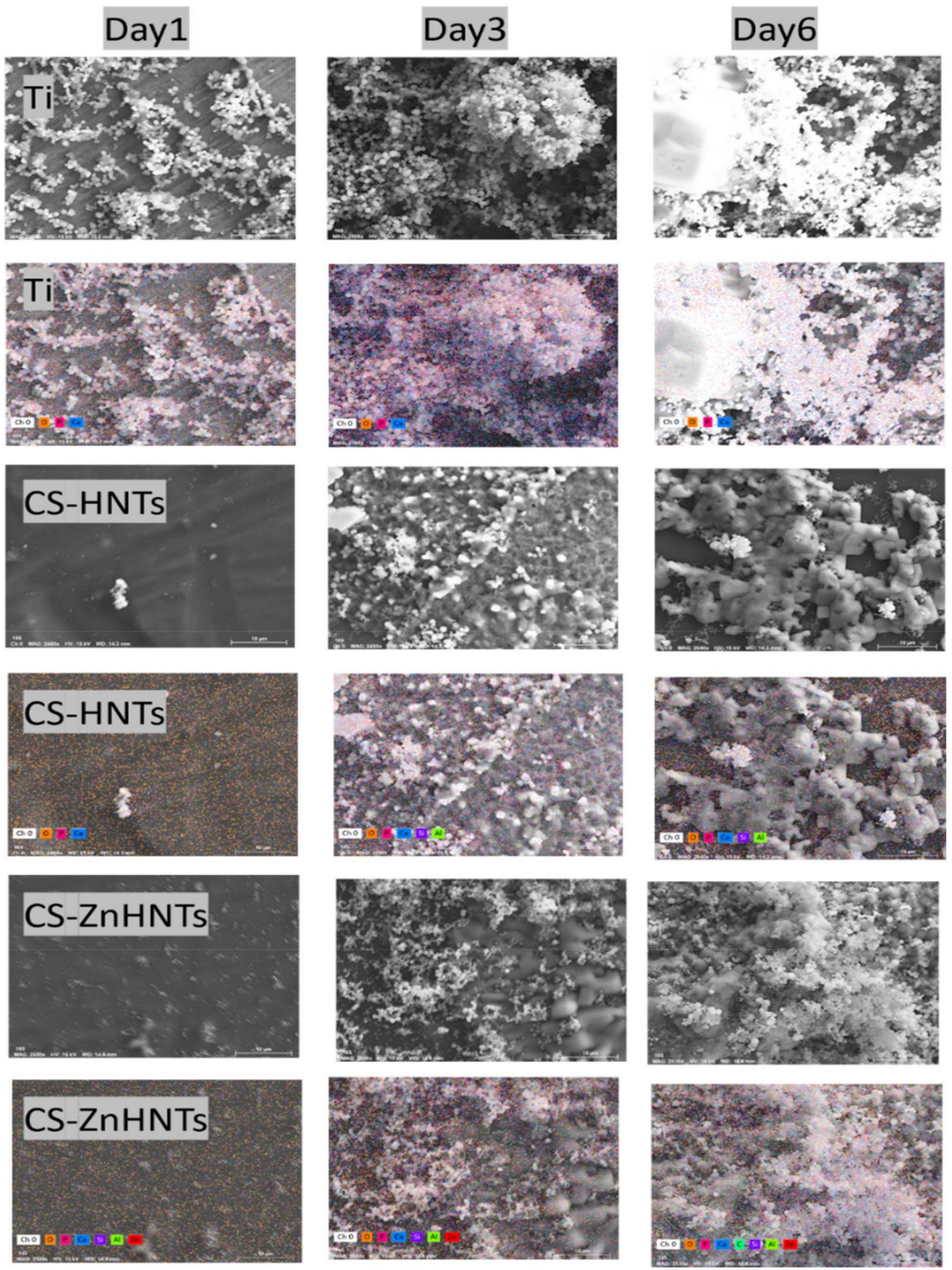

Figure 16. SEM and SEM-EDS map of the samples soaked in simulated body fluid (SBF) for 1, 3, and 6 days.

\section{Conclusions}

Electrodeposition was used to deposit gentamicin-loaded ZnHNTs-chitosan coatings on titanium foil. Morphological surface characterization using SEM-EDS and EDS mapping confirmed the presence of tubular ZnHNTs structures embedded in the coatings, and FTIR analysis confirmed the presence of GS-ZnHNTs-CS in the coatings. Bacterial growth inhibition assays confirmed the successful development of an antibacterial coating. The coating showed cytocompatibility and enhanced cell proliferation in pre-osteoblast cells.

Author Contributions: The authors all contributed to the writing of the manuscript. A.H. and Y.L. conducted the experiments under the direction of D.K.M. All authors reviewed and analyzed the data. All authors have read and agreed to the published version of the manuscript.

Funding: Funding for this study was provided by a grant (to Dr. Mills) from the Louisiana Biomedical Research Network (through an Institutional Development Award (IDeA) from the National Institute of General Medical Sciences of the National Institutes of Health under grant number P20 GM103424-17). The authors also wish to acknowledge the support of the College of Applied and Natural Sciences (Louisiana Tech University) through the Matching Grant Program. 
Acknowledgments: Davis Bailey and Sven Eklund for training.

Conflicts of Interest: The authors declare no conflict of interest.

\section{References}

1. Mattioli-Belmonte, M.; Cometa, S.; Ferretti, C.; Iatta, R.; Trapani, A.; Ceci, E.; Falconi, M.; De Giglio, E. Characterization and cytocompatibility of an antibiotic/chitosan/cyclodextrins nanocoating on titanium implants. Carbohydr. Polym. 2014, 110, 173-182. [CrossRef] [PubMed]

2. Ordikhani, F.; Dehghani, M.; Simchi, A. Antibiotic-loaded chitosan-Laponite films for local drug delivery by titanium implants: Cell proliferation and drug release studies. J. Mater. Sci. Mater. Electron. 2015, 26, 269. [CrossRef] [PubMed]

3. Norowski, P.A.; Courtney, H.S.; Babu, J.; Haggard, W.O.; Bumgardner, J.D. Chitosan coatings deliver antimicrobials from titanium implants: A preliminary study. Implant. Dent. 2011, 20, 56-67. [CrossRef] [PubMed]

4. Swanson, T.E.; Cheng, X.; Friedrich, C. Development of chitosan-vancomycin antimicrobial coatings on titanium implants. J. Biomed. Mater. Res. Part A 2011, 97, 167-176. [CrossRef] [PubMed]

5. Farrokhi-Rad, M.; Fateh, A.; Shahrabi, T. Electrophoretic deposition of vancomycin loaded halloysite nanotubes-chitosan nanocomposite coatings. Surf. Coat. Technol. 2018, 349, 144-156. [CrossRef]

6. Radda'A, N.S.; Goldmann, W.H.; Detsch, R.; Roether, J.A.; Cordero-Arias, L.; Virtanen, S.; Moskalewicz, T.; Boccaccini, A.R. Electrophoretic deposition of tetracycline hydrochloride loaded halloysite nanotubes chitosan/bioactive glass composite coatings for orthopedic implants. Surf. Coat. Technol. 2017, 327, 146-157. [CrossRef]

7. Besinis, A.; Hadi, S.D.; Le, H.R.; Tredwin, C.; Handy, R.D. Antibacterial activity and biofilm inhibition by surface modified titanium alloy medical implants following application of silver, titanium dioxide and hydroxyapatite nanocoatings. Nanotoxicology 2017, 11, 327-338. [CrossRef]

8. Ewald, A.; Glückermann, S.K.; Thull, D.-I.R.; Gbureck, U. Antimicrobial titanium/silver PVD coatings on titanium. Biomed. Eng. Online 2006, 5, 22. [CrossRef]

9. Kazemzadeh-Narbat, M.; Lai, B.F.; Ding, C.; Kizhakkedathu, J.N.; Hancock, R.E.W.; Wang, R. Multilayered coating on titanium for controlled release of antimicrobial peptides for the prevention of implant-associated infections. Biomaterials 2013, 34, 5969-5977. [CrossRef]

10. Peng, Z.-X.; Tu, B.; Shen, Y.; Du, L.; Wang, L.; Guo, S.-R.; Tang, T.-T. Quaternized chitosan inhibits icaA transcription and biofilm formation by Staphylococcus on a titanium surface. Antimicrob. Agents Chemother. 2011, 55, 860-866. [CrossRef]

11. Prasad, K.; Bazaka, O.; Chua, M.; Rochford, M.; Fedrick, L.; Spoor, J.; Symes, R.; Tieppo, M.; Collins, C.; Cao, A.; et al. Metallic biomaterials: current challenges and opportunities. Materials 2017, 10, 884. [CrossRef] [PubMed]

12. Anitha, A.; Sowmya, S.; Jayakumar, R.; Deepthi, S.; Chennazhi, K.; Ehrlich, H.; Tsurkan, M.V.; Jayakumar, R. Chitin and chitosan in selected biomedical applications. Prog. Polym. Sci. 2014, 39, 1644-1667. [CrossRef]

13. Massaro, M.; Lazzara, G.; Milioto, S.; Noto, R.; Riela, S. Covalently modified halloysite clay nanotubes: Synthesis, properties, biological and medical applications. J. Mater. Chem. B 2017, 5, 2867-2882. [CrossRef] [PubMed]

14. Augello, C.; Liu, H. Surface modification of magnesium by functional polymer coatings for neural applications. Surf. Modif. Magnes. Alloys Biomed. Appl. 2015, 335-353. [CrossRef]

15. Farrokhi-Rad, M.; Ghorbani, M. Electrophoretic deposition of titania nanoparticles in different alcohols: Kinetics of deposition. J. Am. Ceram. Soc. 2011, 94, 2354-2361. [CrossRef]

16. Chozhanathmisra, M.; Ramya, S.; Kavitha, L.; Gopi, D. Development of zinc-halloysite nanotube/minerals substituted hydroxyapatite bilayer coatings on titanium alloy for orthopedic applications. Colloids Surf. A Physicochem. Eng. Asp. 2016, 511, 357-365. [CrossRef]

17. Mills, D.; Boyer, C. Method for Metalizing Nanotubes through Electrolysis. U.S. Patent 9,981,074, 29 May 2018.

18. Khaydarov, R.A.; Khaydarov, R.R.; Gapurova, O.; Estrin, Y.; Scheper, T. Electrochemical method for the synthesis of silver nanoparticles. J. Nanopart. Res. 2008, 11, 1193-1200. [CrossRef]

19. Mahmoodi, S.; Sorkhi, L.; Farrokhi-Rad, M.; Shahrabi, T. Electrophoretic deposition of hydroxyapatitechitosan nanocomposite coatings in different alcohols. Surf. Coat. Technol. 2013, 216, 106-114. [CrossRef] 
20. Ismail, A.F.H.; Mohamed, F.; Rosli, L.M.M.; Shafri, M.A.M.; Haris, M.S.; Adina, A.B. Spectrophotometric determination of gentamicin loaded PLGA microparticles and method validation via ninhydrin-gentamicin complex as a rapid quantification approach. J. Appl. Pharm. Sci. 2016, 6, 7-14. [CrossRef]

21. Weisman, J.A.; Jammalamadaka, U.; Tappa, K.; Mills, D.K. Doped halloysite nanotubes for use in the 3D printing of medical devices. Bioengineering 2017, 4, 96. [CrossRef]

22. Lima, E.M.C.X.; Koo, H.; Smith, A.M.V.; Rosalen, P.L.; Cury, A.A.D.B. Adsorption of salivary and serum proteins, and bacterial adherence on titanium and zirconia ceramic surfaces. Clin. Oral Implant Res. 2008, 19, 780-785. [CrossRef] [PubMed]

23. O'Toole, G.A. Microtiter dish biofilm formation assay. J. Vis. Exp. 2011, e2437. [CrossRef] [PubMed]

24. Barrere, F.; Van Blitterswijk, C.; De Groot, K.; Layrolle, P.; Van Blitterswijk, C.A. Nucleation of biomimetic Ca-P coatings on Ti6Al4V from a SBF $\times 5$ solution: Influence of magnesium. Biomaterials 2002, 23, 2211-2220. [CrossRef]

25. Kokubo, T.; Takadama, H. How useful is SBF in predicting in vivo bone bioactivity? Biomaterials 2006, 27, 2907-2915. [CrossRef] [PubMed]

26. Schneider, C.A.; Rasband, W.S.; Eliceiri, K.W. NIH Image to ImageJ: 25 years of image analysis. Nat. Methods 2012, 9, 671-675. [CrossRef] [PubMed]

27. Patel, S.; Jammalamadaka, U.; Sun, L.; Tappa, K.; Mills, D.K. Sustained telease of antibacterial agents from doped halloysite nanotubes. Bioengineering 2015, 3, 1. [CrossRef] [PubMed]

28. Zhitomarsky, I.; Gal-Or, L. Electrophoretic deposition of hydroxyapatite. J. Mater. Sci. Mater. Med. 1997, 8, $213-219$. [CrossRef]

29. Pang, X.; Zhitomirsky, I. Electrophoretic deposition of composite hydroxyapatite-chitosan coatings. Mater. Charact. 2007, 58, 339-348. [CrossRef]

30. Lisuzzo, L.; Cavallaro, G.; Milioto, S.; Lazzara, G. Halloysite nanotubes coated by chitosan for the controlled release of Khellin. Polymers 2020, 12, 1766. [CrossRef]

31. Rapacz-Kmita, A.; Ewa, S.-Z.; Ziąbka, M.; Różycka, A.; Dudek, M. Instrumental characterization of the smectite clay-gentamicin hybrids. Bull. Mater. Sci. 2015, 38, 1069-1078. [CrossRef]

32. Raoufi, D. Synthesis and microstructural properties of $\mathrm{ZnO}$ nanoparticles prepared by precipitation method. Renew. Energy 2013, 50, 932-937. [CrossRef]

33. Sakka, S.; Coulthard, P. Implant failure: Etiology and complications. Medicina Oral Patología Oral y Cirugia Bucal 2011, 16, e42-e44. [CrossRef] [PubMed]

34. Flemming, H.C.; Wingender, J. The biofilm matrix. Nat. Rev. Microbiol. 2010, 8, 623-633. [CrossRef] [PubMed]

35. Jayaramudu, T.; Varaprasad, K.; Pyarasani, R.D.; Reddy, K.K.; Kumar, K.D.; Akbari-Fakhrabadi, A.; Mangalaraja, R.; Amalraj, J. Chitosan capped copper oxide/copper nanoparticles encapsulated microbial resistant nanocomposite films. Int. J. Biol. Macromol. 2019, 128, 499-508. [CrossRef]

36. Mishra, S.K.; Ferreira, J.M.F.; Kannan, S. Mechanically stable antimicrobial chitosan-PVA-silver nanocomposite coatings deposited on titanium implants. Carbohydr. Polym. 2015, 121, 37-48. [CrossRef] [PubMed]

37. Anaya-Esparza, L.M.; Ruvalcaba-Gómez, J.M.; Maytorena-Verdugo, C.I.; González-Silva, N.; Romero-Toledo, R.; Aguilera-Aguirre, S.; Pérez-Larios, A.; Montalvo-González, E. Chitosan-TiO 2 : A versatile hybrid composite. Materials 2020, 13, 811. [CrossRef] [PubMed]

38. Al-Naamani, L.; Dobretsov, S.; Dutta, J. Chitosan-zinc oxide nanoparticle composite coating for active food packaging applications. Innov. Food Sci. Emerg. Technol. 2016, 38, 231-237. [CrossRef]

39. Silva, S.; Henriques, M.; Martins, A.; Oliveira, R.; Williams, D.W.; Azeredo, J. Biofilms of non-Candida albicans Candidaspecies: Quantification, structure and matrix composition. Med. Mycol. 2009, 47, 681-689. [CrossRef]

40. Prasad, A.S. Zinc in human health: effect of zinc on immune Cells. Mol. Med. 2008, 14, 353-357. [CrossRef]

41. Prasad, A.S.; Beck, F.W.; Endre, L.; Handschu, W.; Kukuruga, M.; Kumar, G. Zinc deficiency affects cell cycle and deoxythymidine kinase gene expression in HUT-78 cells. J. Lab. Clin. Med. 1996, 128, 51-60. [CrossRef]

42. Luna, S.M.; Silva, S.S.; Gomes, M.E.; Mano, J.F.; Reis, R.L. Cell adhesion and proliferation onto chitosan-based membranes treated by plasma surface modification. J. Biomater. Appl. 2010, 26, 101-116. [CrossRef] [PubMed]

43. Hu, H.; Zhang, W.; Qiao, Y.; Jiang, X.; Liu, X.; Ding, C. Antibacterial activity and increased bone marrow stem cell functions of $\mathrm{Zn}$-incorporated $\mathrm{TiO}_{2}$ coatings on titanium. Acta Biomater. 2012, 8, 904-915. [CrossRef] [PubMed] 
44. Jin, G.; Cao, H.; Qiao, Y.; Meng, F.; Zhu, H.; Liu, X. Osteogenic activity and antibacterial effect of zinc ion implanted titanium. Colloids Surf. B Biointerfaces 2014, 117, 158-165. [CrossRef] [PubMed]

45. Yu, Y.; Jin, G.; Xue, Y.; Wang, N.; Liu, X.; Sun, J. Multifunctions of dual Zn/Mg ion co-implanted titanium on osteogenesis, angiogenesis and bacteria inhibition for dental implants. Acta Biomater. 2017, 49, 590-603. [CrossRef]

46. O'Connor, J.P.; Kanjilal, D.; Teitelbaum, M.; Lin, S.S.; Cottrell, J. Zinc as a Therapeutic Agent in Bone Regeneration. Materials 2020, 13, 2211. [CrossRef]

47. Qiao, Y.; Zhang, W.; Tian, P.; Meng, F.; Zhu, H.; Jiang, X.; Liu, X.; Chu, P.K. Stimulation of bone growth following zinc incorporation into biomaterials. Biomaterials 2014, 35, 6882-6897. [CrossRef]

48. Yu, J.; Xu, L.; Li, K.; Xie, N.; Xi, Y.; Wang, Y.; Zheng, X.; Chen, X.; Wang, M.; Ye, X. Zinc-modified calcium silicate coatings promote osteogenic differentiation through TGF- $\beta /$ Smad pathway and osseointegration in osteopenic rabbits. Sci. Rep. 2017, 7, 3440. [CrossRef]

49. He, J.; Zhang, B.; Shao, L.; Feng, W.; Jiang, L.; Zhao, B. Biomechanical and histological studies of the effects of active zinc-coated implants by plasma electrolytic oxidation method on osseointegration in rabbit osteoporotic jaw. Surf. Coat. Technol. 2020, 396, 125848. [CrossRef]

(C) 2020 by the authors. Licensee MDPI, Basel, Switzerland. This article is an open access article distributed under the terms and conditions of the Creative Commons Attribution (CC BY) license (http://creativecommons.org/licenses/by/4.0/). 